\title{
Armillaria root rot spreading into a natural woody ecosystem in South
}

\section{Africa}

M.P.A. Coetzee ${ }^{1 *}$, N.Y. Musasira ${ }^{1}$, J. Roux ${ }^{2}$, F. Roets ${ }^{3}$, N.A. van der Merwe ${ }^{1}$, M.J.

Wingfield ${ }^{1}$

Department of Genetics, Forestry and Agricultural Biotechnology, Institute (FABI),

University of Pretoria, Private Bag X20, Pretoria 0028, South Africa

${ }^{2}$ Department of Plant and Soil Sciences, Forestry and Agricultural Biotechnology Institute

(FABI), University of Pretoria, Private Bag X20, Pretoria 0028, South Africa

${ }^{3}$ Department of Conservation Ecology and Entomology, Stellenbosch University, Private Bag

X1, Matieland, South Africa

*Corresponding author: martin.coetzee@ @fabi.up.ac.za (ORCID: 0000-0001-7848-4111)

Running head: Armillaria invading South African fynbos

Keywords: Armillaria mellea, invasion biology, pathogen introduction, population genetics

Conflict of interest: None 


\begin{abstract}
Signs and symptoms of a disease similar to those of Armillaria root rot have recently been observed on various native woody plants on the foothills of Table Mountain in South Africa, one of the most botanically diverse natural environments globally. This is of concern because the root rot fungus Armillaria mellea has previously been shown as an alien pathogen of European origin in planted gardens in the City of Cape Town. An aim of this study was to identify the cause of the root rot disease on the infected plants. Based on DNA-sequence phylogeny, it was shown that isolates collected from at least 16 native tree and woody shrub species represented the non-native A. mellea. Microsatellite markers were then used to determine the genetic diversity and population structure of the A. mellea isolates from Table Mountain and two planted gardens where the pathogen has previously been found. Population genetic analyses revealed low levels of gene diversity and no population differentiation amongst the three populations. The results provide the first firm evidence that A. mellea has escaped the planted environment and invaded a sensitive and ecologically important natural woody environment in South Africa. This is only the second definitive case of a non-native tree pathogen invading a natural ecosystem in the country.
\end{abstract}

\title{
Introduction
}

Armillaria root rot is a disease mainly of woody plants and caused by species in the fungal genus Armillaria. The disease occurs on trees in natural woody ecosystems, and it can also be a serious impediment to forest and fruit tree crops, trees planted in parks and gardens as well as grape vines (Shaw \& Kile, 1991). Armillaria root rot has been associated with forestry crops in South Africa for many years (Bottomley, 1937; Wingfield \& Knox-Davies, 1980), where A. fuscipes is the pathogen responsible for this disease (Coetzee et al., 2000a). This 
species is native in the country (Coetzee et al., 2000a) and elsewhere in Africa (Mwenje et al., 2003; Gezahgne et al., 2004; Mwenje et al., 2006).

In an intriguing discovery, Armillaria root rot, caused by the non-native A. mellea, was found in the Cape Town city centre in 1996 (Coetzee et al., 2001). This led to the conclusion that the fungus was likely introduced into the city (in an area now known as the Company's Garden) by early Dutch settlers during the late 1600 s with crop plants such as citrus trees. Some years later, the disease was found in the nearby Kirstenbosch National Botanical Garden where two species of Armillaria, namely A. mellea and A. gallica, were found (Coetzee et al., 2003; Wingfield et al., 2010). It was assumed that these fungi had also been introduced, with one possibility being that $A$. mellea had spread from the Company's Garden to Kirstenbosch.

In recent years, trees have been observed dying on the foothills of Table Mountain, part of the Table Mountain range of which Kirstenbosch National Botanical Garden forms part (https://www.sanbi.org/gardens/kirstenbosch/overview) (Machingambi, 2013). Symptoms and signs of the disease were typical of Armillaria root rot. This has raised concern and the question as to whether the disease could have arisen from a non-native Armillaria species that escaped from the planted to the natural environment for the first time. The aim of this study was to identify the causal agent of the disease on naturally occurring trees and woody shrubs on the foothills of Table Mountain and to determine whether it could have moved from the planted gardens in Cape Town. 


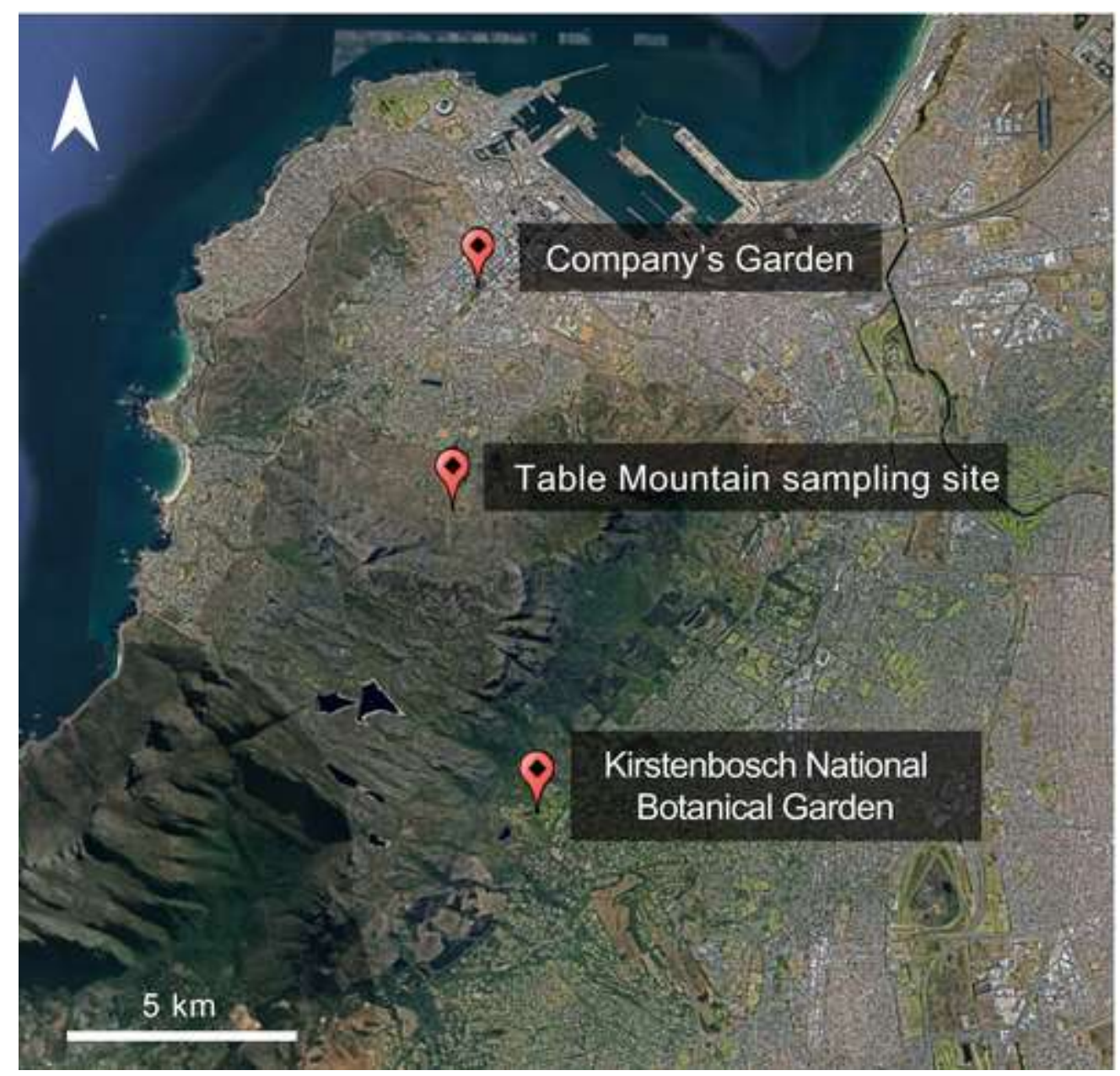

Figure 1. Map showing the collection sites of Armillaria mellea and A. gallica in Cape Town. Map data: SIO, NOAA, U.S. Navy, NGA, GEBCO Image Landsat/Copernicus, Google, AfriGIS (Pty) Ltd.

\section{Materials and methods}

\section{Isolation and cultivation of isolates}

Root samples were collected from infected trees and shrubs in the Kirstenbosch National Botanical Garden and from naturally growing trees on the slopes of Table Mountain (Table 1, Figure 1). Small pieces of white mycelium growing on the roots and root collars were transferred to DBS (Dicholoran, Benomyl and Streptomycin) medium, selective for isolating Armillaria species and other basidiomycetes (Worrall, 1991). Isolation plates were incubated at $24{ }^{\circ} \mathrm{C}$ in the dark until rhizomorphs developed. Tips of the developing rhizomorphs were 
Table 1. Isolates collected in this study.

\begin{tabular}{|c|c|c|c|}
\hline Isolate number & Identity & Host & $\begin{array}{l}\text { Multilocus } \\
\text { genotype }\end{array}$ \\
\hline \multicolumn{4}{|c|}{ Kirstenbosch National Botanical Garden } \\
\hline CMW49610 & Armillaria mellea & Leucadendron strobilium & B \\
\hline CMW49611 & A. mellea & Leucadendron macowanii & $\mathrm{B}$ \\
\hline CMW49612 & A. mellea & Leucospermum conocarpodendron & A \\
\hline CMW49613 & Armillaria gallica & Olea capensis subsp. capensis & \\
\hline CMW49614 & A. gallica & Leucospermum cordifolium & \\
\hline CMW49615 & A. mellea & Ekebergia pterophylla & $A$ \\
\hline CMW49616 & A. mellea & Kiggelaria africana & $A$ \\
\hline CMW49617 & A. gallica & Olea capensis & \\
\hline CMW49618 & A. gallica & Virgilia oroboides & \\
\hline CMW49619 & A. gallica & V. oroboides & \\
\hline CMW49620 & A. mellea & Widdringtonia schwarzii & W \\
\hline CMW49621 & A. mellea & W. schwarzii & $P$ \\
\hline CMW49622 & A. mellea & Leucadendron argenteum & J \\
\hline CMW49623 & A. gallica & Schotia afra & \\
\hline CMW50256 & A. mellea & L. conocarpodendron & $A$ \\
\hline CMW50257 & A. mellea & L. argenteum & C \\
\hline \multicolumn{4}{|l|}{ Table Mountain } \\
\hline CMW49624 & A. mellea & Protea repens & 1 \\
\hline CMW49625 & A. mellea & Podalyria sericea & $\mathrm{C}$ \\
\hline CMW49626 & A. mellea & P. repens & $U$ \\
\hline CMW49627 & A. mellea & Protea neriifolia & $\mathrm{R}$ \\
\hline CMW49628 & A. mellea & Cliffortia ferruginea & $\mathrm{H}$ \\
\hline CMW49629 & A. mellea & V. oroboides & $Q$ \\
\hline CMW49630 & A. mellea & V. oroboides & $\mathrm{F}$ \\
\hline CMW49631 & A. mellea & V. oroboides & $\mathrm{D}$ \\
\hline CMW49632 & A. mellea & V. oroboides & $\mathrm{F}$ \\
\hline CMW49633 & A. mellea & V. oroboides & $\mathrm{D}$ \\
\hline CMW49634 & A. mellea & V. oroboides & $S$ \\
\hline CMW49635 & A. mellea & Protea sericea & V \\
\hline CMW49636 & A. mellea & V. oroboides & $N$ \\
\hline CMW49637 & A. mellea & V. oroboides & $\mathrm{C}$ \\
\hline CMW49638 & A. mellea & Grevillea sp. & $\mathrm{D}$ \\
\hline CMW49639 & A. mellea & L. argenteum & $\mathrm{D}$ \\
\hline CMW49640 & A. mellea & Grevillea sp. & $E$ \\
\hline CMW50258 & A. mellea & V. oroboides & $\mathrm{D}$ \\
\hline
\end{tabular}


transferred to fresh DBS medium until pure cultures were obtained. Pure cultures were grown on malt extract yeast agar (MYA) (10 g/L malt extract, $2 \mathrm{~g} / \mathrm{L}$ yeast extract and $15 \mathrm{~g} / \mathrm{L}$ agar). Isolates previously collected from the Cape Town city centre (Company's Garden; Coetzee et al., 2001) and from Kirstenbosch National Botanical Garden, stored in the culture collection (CMW) of the Forestry and Agricultural Biotechnology Institute (Table 2), were included in the study.

\section{DNA Extraction}

Isolates of Armillaria were grown in liquid malt yeast extract medium (10 g/L malt extract and $2 \mathrm{~g} / \mathrm{L}$ yeast extract) for four weeks in the dark at $24^{\circ} \mathrm{C}$. Mycelium was harvested using a sterilised strainer and lyophilized using a Virtis AdVantage Plus EL-85 Bench-Top Freeze Dryer (SP Scientific, USA). The lyophilized mycelium was ground into a fine powder using a mortar and pestle. DNA extractions were done following the protocol described in Coetzee $e t$ al. (2000b), and the concentration of the DNA was determined using a NanoDrop 1000 spectrophotometer (Thermo Fisher Scientific) and subsequently diluted to a final concentration of $50 \mathrm{ng} / \mu \mathrm{l}$.

\section{ITS PCR amplification and sequencing}

DNA sequences for the ITS region (including the ITS-1 region, 5.8S gene and ITS-2 region of the rRNA operon) were used to identify the isolates. The ITS region was amplified using primers ITS-1 and ITS-4 (White et al., 1990). The PCR mixture included 1 U FastStart Taq DNA polymerase (Roche), $2.5 \mathrm{mM} \mathrm{MgCl} 2$, 1x FastStart Taq PCR reactions buffer, $200 \mu \mathrm{M}$ dNTPs, $0.2 \mu \mathrm{M}$ of each primer and $50 \mathrm{ng}$ DNA. The mixture was adjusted to $25 \mu \mathrm{l}$ with sterile double distilled water. PCR conditions included a hot start for 6 minutes at $96{ }^{\circ} \mathrm{C}$, followed by 30 cycles of denaturation for 30 seconds at $96^{\circ} \mathrm{C}$, primer annealing at $58{ }^{\circ} \mathrm{C}$ for 30 seconds, and elongation for 30 seconds at $72^{\circ} \mathrm{C}$. Amplification was completed with a final 
Table 2. Additional isolates of Armillaria mellea used in this study.

\begin{tabular}{|c|c|c|c|}
\hline Isolate number & Host & Origin & $\begin{array}{l}\text { Multilocus } \\
\text { genotype }\end{array}$ \\
\hline CMW3341 & Quercus robur & CG & A3 \\
\hline CMW3787 & Hydrangium sp. & CG & $\mathrm{M}$ \\
\hline CMW3788 & $\begin{array}{l}\text { Basidiocarp on } \\
\text { Q. robur stump }\end{array}$ & CG & $\mathrm{A} 1$ \\
\hline CMW3973 & Q. robur & CG & A2 \\
\hline CMW3974 & Q. robur & CG & $\mathrm{T}$ \\
\hline CMW3975 & Q. robur & CG & $E$ \\
\hline CMW3976 & Q. robur & CG & $\mathrm{F}$ \\
\hline CMW3977 & Q. robur & CG & $E$ \\
\hline CMW3979 & Q. robur & CG & Y \\
\hline CMW3981 & Q. robur & CG & $\mathrm{O}$ \\
\hline CMW4302 & Q. robur & CG & $x$ \\
\hline CMW4303 & Q. robur & CG & G \\
\hline CMW4304 & Q. robur & CG & $\mathrm{F}$ \\
\hline CMW4305 & Q. robur & CG & $\mathrm{G}$ \\
\hline CMW4306 & Q. robur & CG & Z \\
\hline CMW4307 & Hydrangium sp. & CG & $\mathrm{F}$ \\
\hline CMW7205 & Protea sp. & KNBG & $L$ \\
\hline CMW36264 & Protea sp. & KNBG & K \\
\hline CMW31132 & Ailanthus altissima & China (Yunnan) & \\
\hline CMW31133 & Ketelleria sp. & China (Hubei) & \\
\hline CMW31134 & Unknown & China (Guizhou) & \\
\hline CMW31161 & Pinus armandii & China (Yunnan) & \\
\hline CMW31162 & Fagus grandifolia & USA & \\
\hline CMW31163 & F. grandifolia & USA & \\
\hline CMW31164 & Unknown & Japan & \\
\hline CMW31165 & Pinus strobus & USA (New Hampshire) & \\
\hline CMW31169 & Unknown & Japan & \\
\hline CMW31170 & Unknown & USA (New Hampshire) & \\
\hline CMW31171 & Quercus sp. & USA (New Hampshire) & \\
\hline CMW31172 & Rhododendron sp. & China (Yunnan) & \\
\hline
\end{tabular}

KNBG, Kirstenbosch National Botanical Garden; CG, Company's Garden.
Table 3. Microsatellite markers and primer sequences used in this study

\begin{tabular}{|c|c|c|c|}
\hline \multirow{3}{*}{$\begin{array}{l}\text { Microsatellite } \\
\text { marker (locus) } \\
\text { Am024 }\end{array}$} & \multirow{3}{*}{$\frac{\text { Motif }}{(\mathrm{CAC})_{n}{ }^{\mathrm{b}}}$} & \multicolumn{2}{|c|}{ Primer sequence $\left(5^{\prime}-3^{\prime}\right)^{\mathrm{a}}$} \\
\hline & & $\mathrm{F}$ & VIC-GACCGGACCTCGTATGACAC \\
\hline & & $\mathrm{R}$ & GCACTTTGGTGAAACCATCC \\
\hline \multirow[t]{2}{*}{ Am035 } & \multirow[t]{2}{*}{$(\mathrm{CAC})_{\mathrm{n}}$} & $\mathrm{F}$ & VIC-GCTTCCACGTTGACAAATCC \\
\hline & & $\mathrm{R}$ & CCATCAATGAGACCCCAGAA \\
\hline \multirow[t]{2}{*}{ Am036 } & \multirow[t]{2}{*}{$(\mathrm{AGAT})_{\mathrm{n}}$} & $\mathrm{F}$ & NED-ATTCTTGCAATCCGTCGAGT \\
\hline & & $\mathrm{R}$ & TGCACAGCTCCTGATCATCT \\
\hline \multirow[t]{2}{*}{ Am059 } & \multirow{2}{*}{$(A A A C)_{n}$} & $\mathrm{~F}$ & VIC-GAATTCCATCAGTGGCCAAG \\
\hline & & $\mathrm{R}$ & СTTCTGGGAAGACGCTGGT \\
\hline \multirow[t]{2}{*}{ Am088 } & \multirow[t]{2}{*}{$(A A A G)_{n}$} & $\mathrm{~F}$ & NED-TTGTTAGGCGTCAATCATGTG \\
\hline & & $\mathrm{R}$ & ATCCTGCTGGTGTCGATCTT \\
\hline \multirow[t]{2}{*}{ Am091 } & \multirow[t]{2}{*}{$(C A C)_{n}$} & $\mathrm{~F}$ & VIC-TGCGCAGAGTGTGAGAGAGT \\
\hline & & $\mathrm{R}$ & TACTTAGTGGCACGGTCACG \\
\hline \multirow[t]{2}{*}{ Am094 } & \multirow[t]{2}{*}{$(C A C)_{n}$} & $\mathrm{~F}$ & NED-CGCAGAAGAACATTCGAACA \\
\hline & & $\mathrm{R}$ & AGACGGTAGGTTGGCTGGTA \\
\hline \multirow[t]{2}{*}{ Am 109} & \multirow[t]{2}{*}{$(C A C)_{n}$} & $\mathrm{~F}$ & VIC-ATGAGACCCCAGAAGTTGAAGA \\
\hline & & $\mathrm{R}$ & CACGTTGACAAATCCAATGC \\
\hline \multirow[t]{2}{*}{ Am111 } & \multirow[t]{2}{*}{$(C A C)_{n}$} & $\mathrm{~F}$ & VIC-CGTCGTCCATTAGAGGCAAC \\
\hline & & $\mathrm{R}$ & GCCATTAGTTTGGCGTTGAG \\
\hline \multirow[t]{2}{*}{ Am124 } & \multirow[t]{2}{*}{$(\mathrm{CAC})_{\mathrm{n}}$} & $\mathrm{F}$ & 6-FAM-CTATGATCCGCAAAGCAGTG \\
\hline & & $\mathrm{R}$ & TTGCCAGTTTTCTCGAACAG \\
\hline \multirow[t]{2}{*}{ Am125 } & \multirow[t]{2}{*}{$(\mathrm{CAC}) \mathrm{n}$} & $\mathrm{F}$ & NED-AGCGTGTGATCTCAACAGCA \\
\hline & & $\mathrm{R}$ & CACATCCTGCAАCTTCCTTG \\
\hline \multirow[t]{2}{*}{ Am129 } & \multirow[t]{2}{*}{$(C A C)_{n}$} & $\mathrm{~F}$ & 6-FAM-CCAGGATATGCCTTGTTTGC \\
\hline & & $\mathrm{R}$ & CTGCCAATGCTGTGTGATG \\
\hline
\end{tabular}

${ }^{a}$ VIC, NED, FAM, fluorescent dye labels for genotyping (Applied Biosystems).

${ }^{\mathrm{b}} n=$ number of repeats. 
elongation step for 7 minutes at $72{ }^{\circ} \mathrm{C}$. PCR products were stained with GelRed ${ }^{\mathrm{TM}}$ (Biotium) and electrophoresed on an $1 \%(\mathrm{w} / \mathrm{v})$ agarose gel to determine the size of the amplicons.

PCR products were purified with $8 \mu$ l Exosap (Affymetrix) and used as template for sequencing using a Big Dye $\mathrm{e}^{\mathrm{TM}}$ Terminator Cycle Sequencing kit (Applied Biosystems). Sequencing reactions followed the standard protocol provided by the manufacturer. Sequencing was done in both directions using the primers employed for PCR. Sanger sequencing was conducted at the sequencing facility of the University of Pretoria on a ABI PRISM $^{\mathrm{TM}}$ automated sequencer. CLC Main Workbench v. 7.6.4 (QIAGEN Bioinformatics) was used to assemble reads into consensus sequences, and the sequences were subjected to BLASTn similarity searches against sequences in GenBank (https://www.ncbi.nlm.nih.gov/genbank/).

\section{Phylogenetic analysis}

ITS sequences, together with sequences obtained from GenBank, were aligned using MAFFT (Katoh et al., 2002, Katoh \& Standley, 2013). A cladogram was generated using parsimony in PAUP* v. 10 (Swofford DL, 2002) after excluding parsimony uninformative characters. Tree space was searched using a heuristic search algorithm with random addition of sequences (number of replications $=10$ ), applying a TBR (tree-bisection reconnection) branch swapping algorithm, and auto increase of tree searches. Statistical support for clades was obtained using a bootstrap analysis (number of replications $=1000$ ) with the same setting to obtain the fundamental tree, but with the addition of sequences set to "closest". The cladogram was rooted with $A$. tabescens as the outgroup species as it is closely related to $A$. mellea (Coetzee et al., 2011). 


\section{Identification of genotypes}

Genotypes of the isolates were determined using microsatellite markers (Table 3) developed by Baumgartner et al. (2009). The markers were selected based on positive amplification of the microsatellite containing regions in all the isolates. PCR reactions were performed in 10 $\mu 1$ volumes, containing $0.1 \mu \mathrm{M}$ of each forward and reverse primer, 50 ng of DNA, $1 \mathrm{x}$ FastStart Taq PCR reaction buffer with $\mathrm{MgCl}_{2}, 0.5 \mathrm{U}$ FastStart Taq polymerase and sterile double distilled water. Amplicons were stained using GelRed ${ }^{\mathrm{TM}}$ dye and electrophoresed on a $1.5 \%(\mathrm{w} / \mathrm{v})$ agarose gel to assess their quality. The sizes of the microsatellite amplicons were then determined using GeneScan v4.1 (Applied Biosystems) after electrophoresis on a ABI Prism 3100 Genetic Analyser (Applied Biosystems). LIZ 500 was used as an internal size standard for this analysis. Allele sizes were scored using GeneMapper ${ }^{\circledR}$ v. 4.1 (Applied Biosystems).

\section{Population analysis}

Samples of A. mellea from the three different collection sites (Company's Garden, Kirstenbosch National Botanical Garden and the natural environment on the slopes of Table Mountain) were treated as different populations. POPGENE v. 1.31 (Yeh et al., 1999) was used to calculate the number of alleles, allele frequencies, heterozygosity and Nei's gene diversity (Nei, 1973). Deviation from the Hardy-Weinberg equilibrium for each locus was tested using Genepop v. 4.2 (http://genepop.curtin.edu.au/). Pairwise standardized FST calculations were done for all three populations from Cape Town in GenAlEx v. 6.502 (Peakall \& Smouse, 2006, 2012). Analysis of molecular variance (AMOVA) with 999 permutations was performed in order to compare variation within and between populations. A null hypothesis of no genetic variation was assumed at a $\mathrm{P}$ value of 0.001 . Linkage disequilibrium was determined with MultiLocus v. 1.3 (Agapow \& Burt, 2001) using the index RbarD (10000 permutations). 
Population differentiation was determined with Bayesian clustering analyses in STRUCTURE v. 2.3.4 (Pritchard et al., 2000) without clone correction. Analyses were performed with $K$-value priors ranging from 1 to 10 , with 20 iterations, and a MCMC (Markov Chain Monte Carlo) of 100000 steps each with a burn in of 10000 iterations, using a model of correlated allele frequencies with admixture. The results were subjected to analysis implemented in STRUCTURE HARVESTER (Earl \& vonHoldt, 2012) to determine the optimum $K$ value based on the method outlined in Evanno et al. (2005). In the final analysis, the MCMC (Markov chain) was set at 100000 steps each, with a burn-in of 10000 iterations, $K=2$ and using a model of correlated allele frequencies plus admixture. Results of the analysis were visualized as a bar plot and triangle plot to assess possible admixture in the populations.

\section{Somatic compatibility tests}

Somatic compatibility tests were made to determine whether isolates represented single or multiple genets and to compare the results with those of Coetzee et al. (2001). Isolates for this test were selected for the pairings based on their genotypic differences (Table 1). The exception was CMW49625, CMW4937 (both from Table Mountain) and CMW50257 (from Kirstenbosch National Botanical Garden) that belonged to the same multilocus genotype (Table 1). Cultures were grown on $2 \% \mathrm{MYA}$ at $25^{\circ} \mathrm{C}$ for 21 days. Mycelial plugs from a pair of actively growing isolates were placed $10 \mathrm{~mm}$ apart on 2\% MYA plates, and cultures were incubated at $25{ }^{\circ} \mathrm{C}$ for 6 weeks in the dark. In this test, diploid isolates that are somatically incompatible form barrage (demarcation) lines between each other, while compatible isolates grow into each other (Shaw \& Roth, 1976). Self-pairings were used as positive controls, while pairings with an isolate of A. mellea from Europe (CMW11266) were used as negative control. 


\section{Results}

\section{Isolate Identification}

A total of 31 trees and shrubs with symptoms of Armillaria root rot in Kirstenbosch National Botanical Garden and 18 from Table Mountain were sampled. Sixteen Armillaria isolates were obtained from plants in the Kirstenbosch National Botanical Garden and all sampled trees (18) on Table Mountain yielded isolates (Table 1). BLASTn searches using DNA sequences from these isolates showed that 10 from Kirstenbosch National Botanical Garden were most similar to A. mellea (GenBank accession number: HQ441179 and HQ232290), while the remaining isolates had sequences most similar to sequences of $A$. gallica (GenBank accession number: AY190247). The isolates from Table Mountain had ITS sequences most similar to those of A. mellea on GenBank (GenBank accession number: HQ441179). A phylogenetic tree that included ITS sequences representing A. mellea from different geographic clades showed that A. mellea isolates collected in this study grouped together with isolates of $A$. mellea previously collected from the Company's Garden and that they belonged to the European clade of this species (Figure 2). 


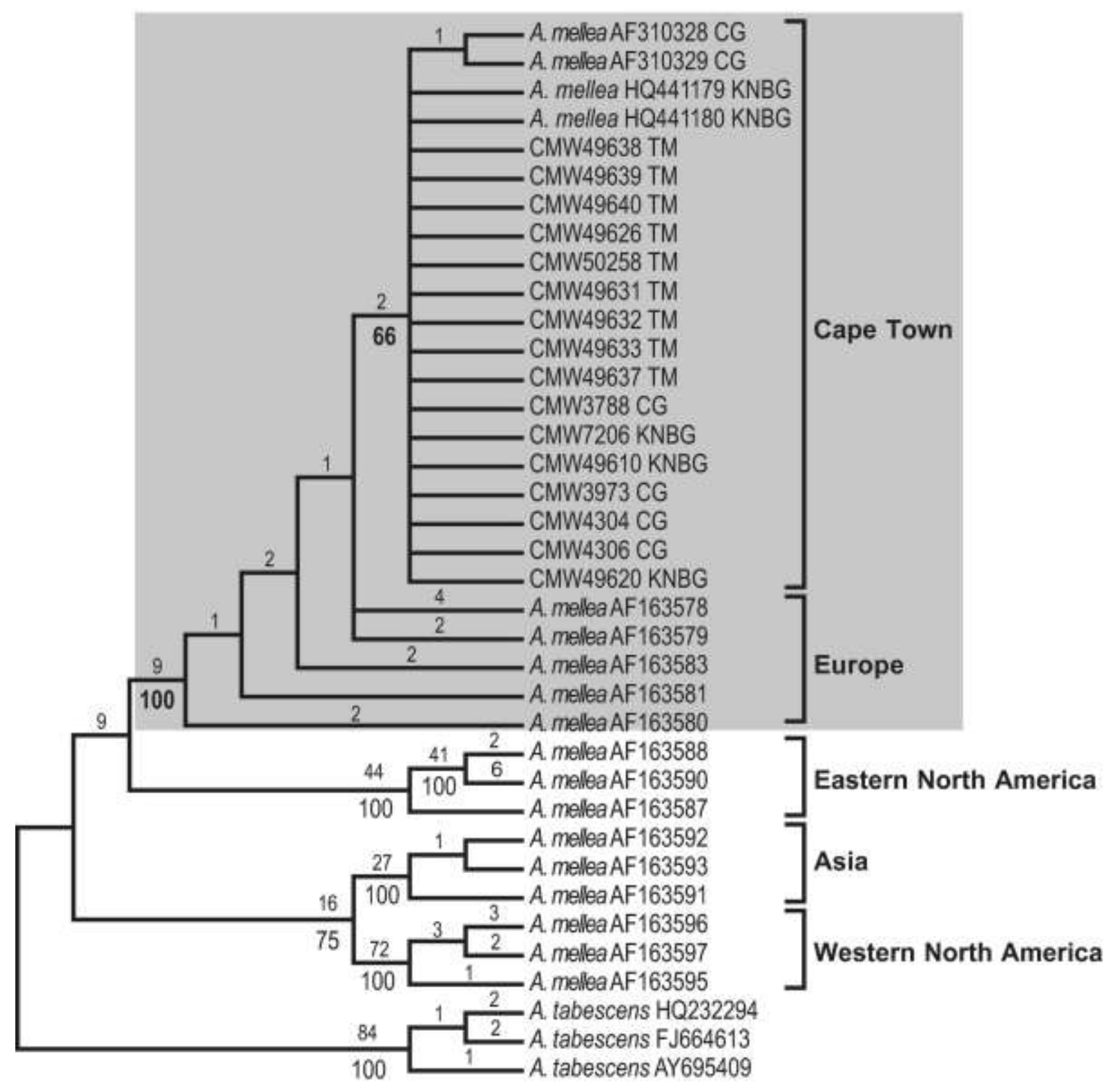

Figure 2. Cladogram showing the clustering of selected isolates based on ITS sequence data. Armillaria tabescens was used as an out-group. Isolates labelled TM are from Table Mountain, CG from Company's Garden and KNBG are from Kirstenbosch National Botanical Garden. Bootstrap values (>60\%) are shown below the tree branches, numbers above the branches indicate the number of parsimony informative character transformations.

\section{Population genetic variation and structure}

In total, 12 primer sets (referred to as microsatellite markers) developed by Baumgartner et al. (2009) were tested for amplification (Table 3). Of the 12 markers utilised in this study, marker AM088 did not amplify, and marker AM109 was excluded from further analyses due to unresolvable extreme stutter during GenScan runs. 
Table 4. Characterization of microsatellite loci for isolates from Cape Town.

\begin{tabular}{|c|c|c|c|c|c|c|c|c|c|c|c|}
\hline \multirow[b]{2}{*}{ Locus (locus code) } & \multicolumn{2}{|c|}{ Allele size } & \multicolumn{2}{|c|}{ Allele frequency } & \multirow[b]{2}{*}{ Heto $_{0}$} & \multirow[b]{2}{*}{$\mathrm{Het}_{\mathrm{E}}$} & \multirow{2}{*}{$\begin{array}{l}\text { Nei's gene } \\
\text { diversity }\end{array}$} & \multicolumn{4}{|c|}{ Deviation from $\mathrm{HWE}^{\mathrm{a}}$} \\
\hline & Allele 1 & Allele 2 & Allele 1 & Allele 2 & & & & CG & KNBG & TM & All \\
\hline AM024 (A) & 194 & 197 & 0.272 & 0.728 & 0.065 & 0.400 & 0.396 & ns & $\star \star \star *$ & $\star \star$ & 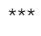 \\
\hline AM035 (B) & 193 & 205 & 0.717 & 0.283 & 0.523 & 0.410 & 0.406 & * & ns & ns & ns \\
\hline AM036 (C) & 183 & 187 & 0.870 & 0.130 & 0.044 & 0.229 & 0.227 & $\star \star$ & $\star \star *$ & - & $* \star *$ \\
\hline AM059 (D) & 220 & 224 & 0.228 & 0.772 & 0.022 & 0.356 & 0.352 & ns & 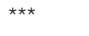 & $\star \star \star ~$ & $* * \star$ \\
\hline AM091 (E) & 224 & - & 1.000 & - & 0.000 & 0.000 & 0.000 & - & - & - & - \\
\hline AM094 (F) & 171 & 174 & 0.467 & 0.533 & 0.283 & 0.503 & 0.498 & ns & 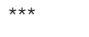 & ns & $\star *$ \\
\hline AM111 (G) & 190 & - & 1.000 & - & 0.000 & 0.000 & 0.000 & - & - & - & - \\
\hline AM124 (H) & 145 & 154 & 0.261 & 0.739 & 0.044 & 0.390 & 0.386 & $\star \star \star$ & $\star *$ & $\star \star \star ~$ & *** \\
\hline AM125 (I) & 194 & 209 & 0.707 & 0.293 & 0.065 & 0.419 & 0.415 & $\star \star$ & 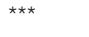 & $\star \star$ & *** \\
\hline AM129 (J) & 152 & - & 1.000 & - & 0.000 & 0.000 & 0.000 & - & - & - & - \\
\hline Mean & & & & & 0.104 & 0.271 & 0.268 & & & & \\
\hline
\end{tabular}

Heto, observed heterozygosity; Hete, expected heterozygosity; CG, Company's Garden; KNBG, Kirstenbosch National Botanic Garden; TM, Table Mountain.

aHWE, Hardy-Weinberg equilibrium. ns, not significant; $* P<0.05 ; * * P<0.01 ; * * * P<0.001$.

Table 5. Gene diversity of isolates from different areas.

\begin{tabular}{lcccc}
\hline Site & $n^{\mathrm{a}}$ & $\mathrm{NG}^{\mathrm{b}}$ & $\mathrm{NA}^{\mathrm{c}}$ & $H^{\mathrm{d}}$ \\
\hline Company's Garden & 16 & 12 & 17 & 0.213 \\
Kirstenbosch National Botanical Garden & 12 & 8 & 20 & 0.333 \\
Table Mountain & 18 & 11 & 16 & 0.184 \\
Isolates from other countries & 13 & 13 & 23 & 0.376 \\
\hline
\end{tabular}

${ }^{a} n$, number of isolates.

${ }^{\mathrm{b}} \mathrm{NG}$, number of genotypes.

${ }^{\mathrm{N}} \mathrm{N}$, number of alleles.

' $H$, Nei's gene diversity. 
One to two alleles were observed per locus and 29 multilocus genotypes (hereafter referred to as genotypes) were identified from the isolates included in this study (Tables 1 and 2). Most of the genotypes were unique while genotypes A to $\mathrm{G}$ were identified in two or more isolates. Among these, genotypes $\mathrm{C}, \mathrm{E}$ and $\mathrm{F}$ were present in different populations (Tables 1 and 2). Allele frequencies ranged from 0.130 to 1 (Table 4). Loci AM091 and AM129 had allele frequencies of 1 and were thus monomorphic. All loci, except for AM035 with a heterozygosity value of 0.523 , showed low values for heterozygosity ( 0 to 0.283$)$ and all loci had low gene diversity ( 0 to 0.498 ) (Table 4$)$. Variation was observed in their deviation from the Hardy-Weinberg equilibrium for loci within the tree populations (Table 4). Among the polymorphic loci, only locus AM035 did not deviate significantly from the Hardy-Weinberg equilibrium when the three populations were treated as a single population (Table 4). The gene diversity $(H)$ ranged from 0.184 to 0.333 for the three different populations (Table 5), with a mean of 0.243 for all the samples combined. The comparative estimated gene diversity of isolates from other countries was 0.376 (Table 5).

A total of 24 allele pairs were identified in the diploid isolates from the three sampling areas. Of these, 14 were shared by isolates from the Company's Garden, Kirstenbosch National Botanical Garden and Table Mountain. Two unique allele pairs $\left(\mathrm{B}_{2} \mathrm{~B}_{2}\right.$ and $\left.\mathrm{D}_{1} \mathrm{D}_{2}\right)$ were identified in isolates from Company's Garden. Allele pairs $\mathrm{A}_{1} \mathrm{~A}_{2}, \mathrm{~F}_{1} \mathrm{~F}_{2}, \mathrm{H}_{1} \mathrm{H}_{2}, \mathrm{I}_{1} \mathrm{I}_{2}$ were shared in isolates from Company's Garden and Table Mountain. Two allele pairs $\left(\mathrm{A}_{1} \mathrm{~A}_{1}\right.$, $\mathrm{D}_{1} \mathrm{D}_{1}$ ) were shared only by isolates from Kirstenbosch National Botanical Garden and Table Mountain, and two allele pairs $\left(\mathrm{C}_{1} \mathrm{C}_{2}, \mathrm{C}_{2} \mathrm{C}_{2}\right)$ were present only in isolates from Kirstenbosch National Botanical Garden. When individual alleles were considered, allele $\mathrm{C}_{2}$ was shared only in isolates from Company's Garden and Kirstenbosch National Botanical Garden. 
Pairwise $F_{S T}$ values ranged from 0.066 to 0.373 , indicating a low level of differentiation among the three populations of isolates. Analysis of population differentiation based on AMOVA revealed that the genetic variation within populations is higher than among populations, and there was no significant population differentiation among the populations $\left(\mathrm{F}_{\mathrm{ST}}=0.185, \mathrm{P}=0.001 ; \Phi \mathrm{pt}=0.375, P=0.001\right)$. The RbarD index indicated non-random mating $(\mathrm{P}<0.0001)$. Results obtained from STRUCTURE indicated a lack of population differentiation and the presence of admixture in all three populations (Figure 3). A triangle plot from STRUCTURE also indicated the presence of gene flow, because alleles found in isolates from Company's Garden were the same as those in isolates from Kirstenbosch National Botanical Garden and Table Mountain.

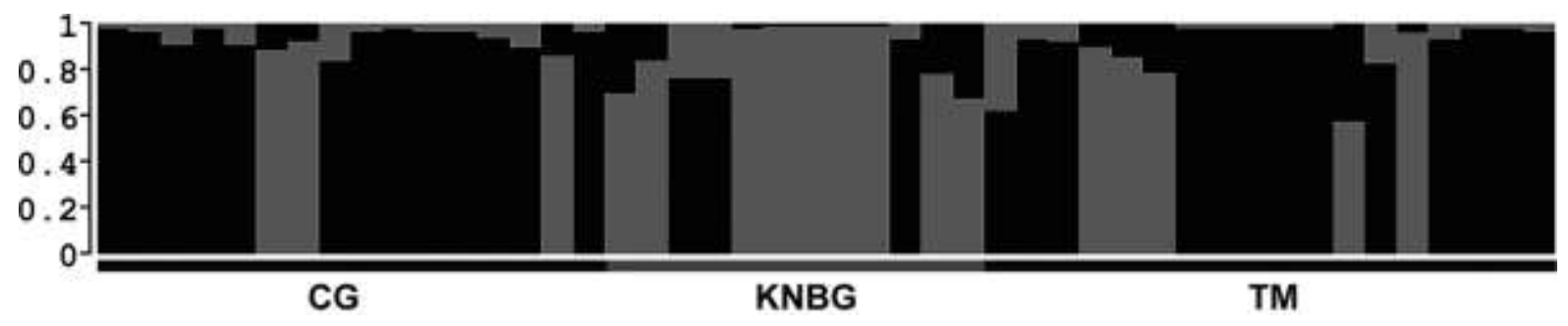

Figure 3. Bar plot from structure-estimated clustering of Armillaria mellea isolates in Cape Town. The bar plot shows different individuals as vertical bars, different colours indicate the affiliation of the genotypes in all populations. CG, Company's Garden; KNBG, Kirstenbosch National Botanical Garden; TM, Table Mountain.

\section{Somatic compatibility tests}

The majority of the isolates tested belonged to the same somatic compatibility group (Table 6). Pairings against isolates CMW49611 and CMW50257, both from Kirstenbosch National Botanical Garden, were the exception in being incompatible with isolates from Company's Gardens and Table Mountain. They consequently represented different genets in relation to the rest of the isolates tested. However, pairings between these two isolates were compatible indicating that they represent the same genet. 
Table 6. Results from somatic compatibility tests.

\begin{tabular}{|c|c|c|c|c|c|c|c|c|c|c|c|c|c|}
\hline Isolate & Genotype & CMW3981 & CMW3787 & CMW4306 & CMW4307 & CMW49611 & CMW50257 & CMW49624 & CMW49625 & CMW49636 & CMW49637 & CMW49629 & CMW11266 \\
\hline CMW3981 (CG) & 0 & + & + & + & + & - & - & + & + & + & + & + & - \\
\hline CMW3787 (CG) & M & + & + & + & + & - & - & + & + & + & + & + & - \\
\hline CMW4306 (CG) & Z & + & + & + & + & - & - & + & + & + & + & + & - \\
\hline CMW4307 (CG) & $\mathrm{F}$ & + & + & + & + & - & - & + & + & + & + & + & - \\
\hline CMW49611 (KNBG) & B & - & - & - & - & + & + & - & - & - & - & - & - \\
\hline CMW50257 (KNBG) & C & - & - & - & - & + & + & - & - & - & - & - & - \\
\hline CMW49624 (TM) & 1 & + & + & + & + & - & - & + & + & + & + & + & - \\
\hline CMW49625 (TM) & C & + & + & + & + & - & - & + & + & + & + & + & - \\
\hline CMW49636 (TM) & $N$ & + & + & + & + & - & - & + & + & + & + & + & - \\
\hline CMW49637 (TM) & C & + & + & + & + & - & - & + & + & + & + & + & - \\
\hline CMW49629 (TM) & Q & + & + & + & + & - & - & + & + & + & + & + & - \\
\hline CMW11266 & & - & - & - & - & - & - & - & - & - & - & - & + \\
\hline
\end{tabular}

+, formation of a single colony between the pairings; -, formation of a barrage zone between the pairings. CG, Company's Garden; KNBG, Kirstenbosch National Botanical Garden; TM, Table Mountain. asolate used as a negative control in the somatic compatibility tests. 


\section{Discussion}

The results of this study provide clear evidence that Armillaria root rot has spread to the natural woody ecosystem on the Table Mountain range on the outskirts of the city of Cape Town. Only A. mellea, one of the two non-native Armillaria species known in planted gardens in Cape Town (Coetzee et al., 2003; Wingfield et al., 2010), was associated with this new invasion. Population genetic analyses further showed that isolates of $A$. mellea from the planted gardens of Kirstenbosch National Botanical Garden and Company's Garden were related. This provides strong evidence that the pathogen most likely originated from these gardens and that it has spread to the natural woody forests (Afromontane forests) and shrubland vegetation (mountain fynbos) on the foothills of Table Mountain.

Genetic variation was observed within and between populations of A. mellea in Cape Town, indicating that recombination is occurring among these populations. Furthermore, results of the population genetic analyses showed that gene flow between the populations is occurring. There are two possible explanations for the shared genotypes and somatic compatibility groups between the different populations. Either infected material has physically been moved from one area to another, or gene flow occurred through dispersal of basidiospores (meiospores), after which offspring from individuals in one area have become established in a new area. The geographic proximity of the Company's Garden and the invaded area at the foot of Table Mountain makes anthropogenic movement of material possible, but it seems unlikely that plant material would have been translocated from the gardens to the natural vegetation on Table Mountain. A more probable explanation would be spread via basidiospores. Armillaria mellea is known to regularly form sporulating basidiocarps in the Company's Garden and Kirstenbosch and the invaded sites are upwind from the Company's Garden where strong north-westerly winds regularly blow during winter storms. It is known 
that wind facilitates the spread of spores over long distances, and that new Armillaria infection areas can be established by spore dispersal (e.g. Power et al., 2008, Baumgartner et al., 2009; Heinzelmann et al., 2012; Travadon et al., 2012; Dutech et al., 2017).

Relatively low genetic diversity observed in the present study using 10 microsatellite markers is consistent with the results obtained by Coetzee et al. (2001), where only two microsatellite markers were used. This low genetic diversity and lack of population differentiation suggests that the introduction of A. mellea into South Africa represents a single event. During the $1600 \mathrm{~s}$, potted citrus trees were brought into the country from Europe and it is assumed that these trees may have been the source of the inoculum (Coetzee et al., 2001). It is thus reasonable to assume that different genotypes were introduced on these plants during a single event, where they became established in the planting area. Subsequently, these genotypes spread to natural areas on Table Mountain as is evident from the genotypes shared between the Company's Garden and the sampling area at the foot of the mountain.

Somatic incompatibility tests were undertaken to determine if isolates with different multilocus genotypes are somatically compatible, and also to compare the results with those of Coetzee et al. (2001) that emerged at a time when microsatellite analyses were limited. Results of these tests showed that isolates with different multilocus genotypes are compatible with each other and that more than one genet is present in Cape Town. Pairings between isolates from the Company's Garden were compatible, which is congruent with the findings of Coetzee et al. (2001) who showed that only one genet is present at that location. Isolates from Table Mountain were compatible with each other and with those from the Company's Garden. In contrast, isolates of A. mellea from Kirstenbosch National Botanical Garden that were included in the test did not belong to the same somatic compatibility group as those 
from the Company's Garden and Table Mountain, despite the similarity in microsatellite profiles of one of the isolates with that of isolates from Table Mountain. Somatic compatibility is controlled by the het (also referred to as vic) loci and the differences in the het loci between two strains leads to apoptosis of hyphal cells, which manifest as a barrage zone (reviewed in Glass \& Dementhon, 2006; Paoletti, 2016; Daskalov et al., 2017). Because this is controlled by a few loci, isolates that are somatically compatible may not be genetically identical as revealed by molecular marker analysis of other fungi (Jacobson et al., 1993; Appel \& Gordon, 1996) and as has been found in the present study.

Results of the population genetic analyses in this study indicate that recombination is occurring among isolates at the different sampling sites. Phylogentic analyses have previously shown that A. mellea was introduced into South Africa from Europe (Coetzee et al. 2001). The fungus in Europe is known to be heterothallic (Guillaumin et al. 1991) and this would facilitate recombination in the introduced range in South Africa.

After the discovery of A. mellea in Company's Garden, Armillaria root rot was also identified in Kirstenbosch National Botanical Garden on native Protea and Leucadendron species. Armillaria mellea and A. gallica were identified as the causal agents of root rot on these fynbos species that are icons of the Cape Floristic Region of South Africa (Coetzee et al., 2003). Based on DNA sequence similarity with isolates from Japan, it was suggested that $A$. gallica in the botanical garden originated in Asia. Another introduced tree pathogen, Phytopthora cinnamomi, is known to have invaded natural woody ecosystems in Africa, and in particular the Cape Floristic Region where it is devastating on Leucadendron and Leucospermum species (Von Broembsen, 1984; Von Broembsen \& Kruger, 1985; Linde et al., 1997). This pathogen also causes serious disease problems on fynbos species in the 
Kirstenbosch National Botanical Garden. There is consequently a strong possibility of $A$. gallica moving from Kirstenbosch National Botanical Garden up the mountain and causing serious damage to the natural woody ecosystem, similar to A. mellea and P. cinnamomi.

In this study it was shown that A. mellea is spreading and causes Armillaria root rot on woody plants and trees in natural ecosystems in the Cape Town area. The spread of the fungus is presumed to be due to basidiospore dispersal. The results suggest that A. mellea escaped the Company's Garden, the most likely original infection centre, and established a secondary infection centre in Kirstenbosch National Botanical Garden. Importantly, the pathogen is now moving into natural environments on Table Mountain, a world heritage site that includes large numbers of rare and endangered woody plant species. This study provides an example of an alien phytopathogenic fungus that was introduced into a man-made environment (botanical gardens), from which it subsequently escaped into a natural ecosystem and where it is now posing a significant threat to the health of indigenous trees and woody plants.

\section{Acknowledgments}

This work is based on the research supported by the National Research Foundation of South Africa (NRF) (Grant number: 91570). The grant holders acknowledge that opinions, findings, and conclusions or recommendations expressed in any publication generated by the NRF supported research are that of the authors and that the NRF accepts no liability whatsoever in this regard. We also thank the members of the Tree Protection Co-operative Programme (TPCP), the THRIP initiative of the Department of Trade and Industry, the DST/NRF Centre of Excellence in Tree Health Biotechnology (CTHB) of the Forestry and Agricultural Biotechnology Institute (FABI), University of Pretoria, South Africa for financial support to 
undertake this work. We also express our appreciation to Quentin Santana (Department of Genetics, FABI, University of Pretoria) who assisted us with some of the population genetic analyses and Monique McQuillan (South African National Biodiversity Institute) for her assistance during collecting samples in Kirstenbosch National Botanical Garden. Conflict of interest: None.

\section{References}

Agapow P-M, Burt A, 2001. Indices of multilocus linkage disequilibrium. Molecular Ecology Notes 1, 101-102.

Appel DJ, Gordon TR, 1996. Relationships among pathogenic and nonpathogenic isolates of Fusarium oxysporum based on the partial sequence of the intergenic spacer region of the ribosomal DNA. Molecular Plant-Microbe Interactions 9, 125-38.

Baumgartner K, Grubisha LC, Fujiyoshi P, Garbelotto M, Bergemann SE, 2009.

Microsatellite markers for the diploid basidiomycete fungus Armillaria mellea. Molecular Ecology Resources 9, 943-6.

Bottomley AM, 1937. Some of the more important diseases affecting timber plantations in the Transvaal. South African Journal of Science 33, 373-6.

Coetzee MPA, Bloomer P, Wingfield MJ, Wingfield BD, 2011. Paleogene radiation of a plant pathogenic mushroom. Plos One 6, e28545.

Coetzee MPA, Wingfield BD, Coutinho TA, Wingfield MJ, 2000a. Identification of the causal agent of Armillaria root rot of Pinus species in South Africa. Mycologia 92 , 777-85. 
Coetzee MPA, Wingfield BD, Harrington TC, Dalevi D, Coutinho TA, Wingfield MJ, 2000b. Geographical diversity of Armillaria mellea ss based on phylogenetic analysis. Mycologia 92, 105-13.

Coetzee MPA, Wingfield BD, Harrington TC, Steimel J, Coutinho TA, Wingfield MJ, 2001. The root rot fungus Armillaria mellea introduced into South Africa by early Dutch settlers. Molecular Ecology 10, 387-96.

Coetzee MPA, Wingfield BD, Roux J, Crous PW, Denman S, Wingfield MJ, 2003.

Discovery of two northern hemisphere Armillaria species on Proteaceae in South Africa. Plant Pathology 52, 604-12.

Daskalov A, Heller J, Herzog S, Fleißner A, Glass NL, 2017. Molecular mechanisms regulating cell fusion and heterokaryon formation in filamentous fungi. Microbiology Spectrum $\mathbf{5}$.

Dutech C, Labbé F, Capdevielle X, Lung-Escarmant B, 2017. Genetic analysis reveals efficient sexual spore dispersal at a fine spatial scale in Armillaria ostoyae, the causal agent of root-rot disease in conifers. Fungal Biology 121, 550-60

Earl DA, vonHoldt BM, 2012. STRUCTURE HARVESTER: a website and program for visualizing STRUCTURE output and implementing the Evanno method. Conservation Genetics Resources 4, 359-61.

Evanno G, Regnaut S, Goudet J, 2005. Detecting the number of clusters of individuals using the software structure: a simulation study. Molecular Ecology 14, 2611-20.

Gezahgne A, Coetzee MPA, Wingfield BD, Wingfield MJ, Roux J, 2004. Identification of the Armillaria root rot pathogen in Ethiopian plantations. Forest Pathology 34, 13345.

Glass NL, Dementhon K, 2006. Non-self recognition and programmed cell death in filamentous fungi. Current Opinion in Microbiology 9, 553-8. 
Guillaumin J-J, Anderson JB, Korhonen K, 1991. Life cycle, interfertility, and biological species. In: Shaw CG, Kile GA, eds. Armillaria Root Disease. Agriculture Handbook No. 691. Washington D.C.: Forest Service United States Department of Agriculture, $10-20$.

Heinzelmann R, Rigling D, Prospero S, 2012. Population genetics of the wood-rotting basidiomycete Armillaria cepistipes in a fragmented forest landscape. Fungal Biology 116, 985-94.

Jacobson KM, Miller OK, Turner BJ, 1993. Randomly amplified polymorphic DNA markers are superior to somatic incompatibility tests for discriminating genotypes in natural populations of the ectomycorrhizal fungus Suillus granulatus. Proceedings of the National Academy of Sciences 90, 9159-63.

Katoh K, Misawa K, Kuma K, Miyatam T, 2002. MAFFT: a novel method for rapid multiple sequence alignment based on fast Fourier transform. Nucleic Acids Research 30, 3059-66.

Katoh K, Standley DM, 2013. MAFFT Multiple Sequence Alignment Software Version 7: Improvements in performance and usability. Molecular Biology and Evolution 30, $772-80$.

Linde C, Drenth A, Kemp GHJ, Wingfield MJ, Von Broembsen SL, 1997. Population structure of Phytophthora cinnamomi in South Africa. Phytopathology 87, 822-7.

Machingambi NM, 2013. An investigation into the death of native Virgilia trees in the Cape Floristic Region of South Africa. Stellenbosch, South Africa: Stellenbosch University, MSc. thesis.

Mwenje E, Wingfield BD, Coetzee MPA, Nemato H, Wingfield MJ, 2006. Armillaria species on tea in Kenya identified using isozyme and DNA sequence comparisons. Plant Pathology 55, 343-50. 
Mwenje E, Wingfield BD, Coetzee MPA, Wingfield MJ, 2003. Molecular characterisation of Armillaria species from Zimbabwe. Mycological Research 107, 291-6.

Nei M, 1973. Analysis of gene diversity in subdivided populations. Proceedings of the National Academy of Sciences 70, 3321-3.

Paoletti M, 2016. Vegetative incompatibility in fungi: From recognition to cell death, whatever does the trick. Fungal Biology Reviews 30, 152-62.

Peakall R, Smouse PE, 2012. GenAlEx 6.5: genetic analysis in Excel. Population genetic software for teaching and research—an update. Bioinformatics 28, 2537-9.

Peakall ROD, Smouse PE, 2006. GENALEX 6: genetic analysis in Excel. Population genetic software for teaching and research. Molecular Ecology Notes 6, 288-95.

Power MWP, Ramsfield TD, Hood IA, 2008. Detection of Armillaria basidiospore dispersal. New Zealand Plant Protection 61, 35-40.

Pritchard JK, Stephens M, Donnelly P, 2000. Inference of population structure using multilocus genotype data. Genetics 155, 945-59.

Shaw CG, Kile GA, 1991. Armillaria Root Disease. Agriculture Handbook No. 691. Washington, D.C., USA: Forest Service, United States Department of Agriculture.

Shaw CG, Roth LF, 1976. Persistence and distribution of a clone of Armillaria mellea in a Ponderosa pine forest. Phytopathology 66, 1210-3.

Swofford DL, 2002. PAUP*: Phylogenetic Analysis Using Parsimony (*and Other Methods). Vers. 4 Sunderland, Massachusetts: Sinauer Associates.

Travadon R, Smith ME, Fujiyoshi P, Douhan GW, Rizzo DM, Baumgartner K, 2012. Inferring dispersal patterns of the generalist root fungus Armillaria mellea. New Phytologist 193, 959-69. 
Von Broembsen SL, 1984. Occurrence of Phytophthora cinnamomi on indigenous and exotic hosts in South Africa, with special reference to the South-Western Cape Province. Phytophylactica 16, 221-6.

Von Broembsen SL, Kruger FJ, 1985. Phytophthora cinnamomi associated with mortality of native vegetation in South Africa. Plant Disease 69, 715-7.

White TJ, Bruns T, Lee S, Taylor J, 1990. Amplification and direct sequencing of fungal ribosomal RNA genes for phylogenetics. In: Innis MA, Gelfand DH, Sninsky JJ, White TJ, eds. PCR Protocols: A Guide to Methods and Applications. New York, NY, USA: Academic Press, 315-22.

Wingfield MJ, Coetzee MPA, Crous PW, Six D, Wingfield BD, 2010. Fungal phoenix rising from the ashes? IMA Fungus 1, 149-53.

Wingfield MJ, Knox-Davies PS, 1980. Observations on diseases in Pine and Eucalyptus plantations in South Africa. Phytophylactica 12, 57-63.

Worrall JJ, 1991. Media for selective isolation of hymenomycetes. Mycologia 83, 296-302.

Yeh FC, Yang R-C, Boyle T, Mao JX 1999. POPGENE, the user-friendly shareware for population genetic analysis. University of Alberta, Canada: Molecular Biology and Biotechnology Centre. 